\title{
Dampak Pandemi Covid-19 terhadap Perilaku Belajar, Interaksi Sosial dan Kesehatan bagi Mahasiswa FKIP Universitas Palangka Raya \\ Zuly Daima Ulfa ${ }^{a}$, Ujen Zenal Mikdar ${ }^{b}$ \\ abUniversitas Palangka Raya, Indonesia
}

Correspondence: zuly.daima@fkip.upr.ac.id

Received: 22 Jul 2020 Accepted: 14 Oct 2020 Published: 31 Oct 2020

\begin{abstract}
The covid-19 pandemic forced restrictions on social, economic, religious activities including college activities. The closure of several public facilities, sports arenas, shops and lectures conducted online has an impact on Palangka Raya University (UPR) students. The study aims to analyze the changes in learning, social and health of UPR students. This study was quantitative research and used cross-sectional design. Samples were FKIP UPR students that were selected by simple random sampling. Data were collected using online questionnaire. The impact of the covid-19 pandemi for students in college activities is the adjustment of online methode, because some areas are constrained by internet signal. Social communication is increasing in cyberspace, as a result of can't meet directly. Students become more concerned about health behavior, which is mostly applied is washing hands. Covid-19 pandemic has an impact on learning behavior, social and health, but from the constraints experienced, students become more adaptive to identify technologies that can support learning, increasing social relations and application of healthy lifestyles. The conclusion is pandemic has a negative impact on learning which is related to unstable signal, but there is also positive impact, which is improving skills related to using technology, social communication and health behavior.
\end{abstract}

Keywords: college; dietary habit; imunity; new normal; sport

\begin{abstract}
Abstrak
Pandemi covid-19 memaksa pembatasan aktivitas sosial, ekonomi, keagamaan termasuk kegiatan perkuliahan. Penutupan beberapa fasilitas umum, arena olahraga dan pertokoan serta perkuliahan dilakukan secara online memberikan dampak pada mahasiswa Universitas Palangka Raya (UPR). Penelitian bertujuan menganalisis perubahan belajar, sosial dan kesehatan mahasiswa UPR. Penelitian merupakan riset kuantitatif. Desain yang digunakan adalah crossectional. Penelitian dilakukan pada mahasiswa FKIP UPR. Sampel adalah mahasiswa FKIP UPR yang dipilih secara simpel random sampling. Pengumpulan data menggunakan kuesioner online. Dampak pandemi covid-19 bagi mahasiswa dalam kegiatan perkuliahan adalah penyesuaian perkuliahan online, karena beberapa daerah terkendala sinyal internet. Komunikasi sosial di dunia maya meningkat, sebagai akibat tidak bisa tatap muka secara langsung. Mahasiswa menjadi lebih memperhatikan perilaku kesehatan, yang banyak diterapkan adalah mencuci tangan. Pandemi covid-19 memberikan dampak terhadap perilaku belajar, sosial dan kesehatan, namun dari kendala-kendala yang dialami, mahasiswa menjadi lebih adaptif yaitu mengenali teknologi yang dapat mendukung capaian belajar, meningkatnya interaksi sosial melalui komunikasi online serta peningkatan penerapan pola hidup sehat. Simpulan penelitian adalah pandemi memberikan dampak negatif yaitu mahasiswa kesulitan belajar secara teknis akibat perkuliahan online, namun banyak pula dampak positif yaitu meningkatnya keterampilan terkait penggunaan teknologi, komunikasi sosial dan perilaku kesehatan.
\end{abstract}

Kata kunci: kuliah; pola makan; imunitas; new normal; olahraga 


\section{Pendahuluan}

Pandemi global dinyatakan oleh WHO (World Health Organization) pada 11 Maret 2020 akibat wabah covid-19 yang menyebar luas. WHO meminta negara-negara termasuk Indonesia untuk mengambil tindakan yang mendesak dan agresif untuk mencegah dan mengendalikan covid-19. Kasus terdeteksi pertama kali di Kalimantan Tengah pada 20 Maret 2020 sehingga Kalimantan Tengah meningkatkan status menjadi gawat darurat (Gugus Tugas Covid-19 Ka Hal serupa dijelaskan oleh Nicola, Alsafi, Sohrabi, Kerwan, \& Al-jabir (2020) bahwa terdapat kesenjangan pada suatu populasi yang memiliki pendapatan tinggi dapat memenuhi akses teknologi dan mengikuti pendidikan secara digital. limantan Tengah, 2020).

Sebuah penelitian menunjukkan bahwa memiliki sikap sebagian besar baik yaitu mematuhi himbauan pemerintah terkait protokol kesehatan, namun lebih dari $80 \%$ orang disibukkan oleh pemikiran tentang covid-19. Informasi tentang covid-19 beredar luas baik di televisi, media masa maupun media sosial sehingga membuat orang selalu memikirkan dan mencemaskan tentang covid-19. Hal tersebut dikawatirkan berdampak pada kesehatan mental seseorang. Penelitian tersebut menunjukkan beberapa dampak yang dialami terkait covid-19 yaitu kesulitan tidur 12,5\%, paranoia tentang infeksi covid-19 37,8\% dan merasakan tekanan akibat media sosial sebesar 36,4\% (Roy et al., 2020).

Dampak covid-19 juga dialami oleh mahasiswa. Perkuliahan daring dipilih sebagai solusi dalam kegiatan perkuliahan konvensional yang tidak dapat diterapkan akibat pembatasan sosial. Penelitian mengenai pembelajaran online di Prodi Pendidikan Biologi Fakultas Keguruan dan Ilmu Pendidikan (FKIP) Universitas Sulawesi Barat (Unsulbar) diketahui mahasiswa telah memiliki fasilitas-fasilitas dasar yang dibutuhkan untuk mengikuti pembelajaran online sehingga mampu mendorong munculnya kemandirian belajar dan motivasi untuk lebih aktif dalam belajar. Pembelajaran jarak jauh meminimalisir kerumunan sebagai langkah nyata menerapkan protokol kesehatan dalam rangka pencegahan penularan covid-19 (Firman \& Rahayu, 2020)

Namun pada beberapa penelitian, perkuliahan daring membutuhkan penyesuaian sehingga menjadi kendala bagi mahasiswa. Penelitian pada mahasiswa ilmu keolahragaan Unesa, kendala yang dirasakan pada perkuliahan daring meliputi paket kuota data dan sinyal yang minim ditambah dengan teknis perkuliahan yang memberatkan mahasiswa dengan penugasan yang banyak dengan deadline pengerjaan yang pendek (Sulata \& Hakim, 2020).

Nicola, Alsafi, Sohrabi, Kerwan, \& Al-jabir (2020) menuliskan bahwa pandemi covid-19 berdampak banyak hal selain kematian global, yaitu pada sektor ekonomi dan berdampak pada bidang lain termasuk pendidikan. Permasalahan dalam bidang pendidikan terkait akses informasi teknologi dan media dimana terdapat kesenjangan pada suatu populasi yang memiliki pendapatan tinggi dapat memenuhi akses teknologi dan mengikuti pendidikan secara digital.

Pandemi covid-19 membuat aktivitas dibatasi, baik kegiatan perkantoran, perkuliahan atau sekolah maupun aktivitas lainnya. Universitas Palangka Raya menerbitkan edaran bahwa mulai 21 Maret 2020 perkuliahan dilakukan secara online. Studi Pendahuluan dilakukan secara online menggunakan google form pada mahasiswa PJKR FKIP UPR pada tanggal 20-25 Mei 2020 menunjukkan bahwa hampir semua kegiatan dilakukan di rumah saja. Mahasiswa yang memiliki rutinitas olahraga pun harus terhenti karena pusat kebugaran dan pusat latihan ditutup. Beberapa memilih latihan sendiri di rumah, namun ada pula yang mengalihkan aktivitasnya, dengan tidak latihan, membantu orang tua atau bekerja untuk mencari tambahan uang saku. 
Mahasiswa yang sebagian dari mereka merupakan "anak rantau” berasal dari kabupaten atau provinsi lain, bahkan berasal dari luar pulau, juga membutuhkan perhatian. Mahasiswa mengalami dampak secara langsung maupun tidak langsung, termasuk dalam hal keuangan. Mahasiswa sebagian tidak dapat mengikuti kuliah online karena tidak memiliki uang untuk membeli kuota internet, karena uang saku berkurang atau tidak ada. Sebagian kesulitan bekerja karena jalan-jalan ditutup atau tempat bekerja mereka tidak beroperasional, sebagian pula merasakan dampak tidak langsung berupa penurunan bahkan berhentinya uang saku karena orang tua mereka tidak lagi bisa bekerja. Keterbatasan uang saku membuat pola makan tidak teratur, makan seadanya. Beberapa interaksi sosial dilakukan (bertemu langsung) tetapi akses jalan banyak ditutup.

Penelitian perlu dilakukan untuk menganalisis perubahan aktivitas belajar, interaksi sosial, perilaku kesehatan akibat pandemi covid-19. Urgensi dalam penelitian ini adalah dimana pandemi covid-19 merupakan hal yang baru sehingga perlu dikaji mengenai dampak yang dialami sehingga dapat dirancang upaya mengatasi kesulitan akibat dampak covid-19 sebagai upaya adaptasi kebiasaan baru. Tujuan penelitian untuk menganalisis perubahan aktivitas belajar, interaksi sosial dan perilaku kesehatan akibat pandemi, agar dapat mempersiapkan dan melakukan hal yang tepat pada era adaptasi kebiasaan baru. Pandemi masih ada namun beberapa aktivitas harus tetap berjalan agar produktivitas tidak terhenti, harapannya penelitian ini memberikan kontribusi dalam perilaku adaptasi kebiasaan baru.

\section{Metode Penelitian}

Penelitian dilakukan pada bulan Juni 2020. Subyek yang diteliti adalah mahasiswa Universitas Palangka Raya. Penelitian dilakukan dengan pendekatan kuantitatif. Jenis penelitian adalah deskriptif. Desain yang digunakan menggunakan pendekatan cross sectional. Pengumpulan data menggunakan kuesioner dampak pandemi covid-19 bagi mahasiswa FKIP UPR. Kuesioner disusun oleh peneliti, berupa pertanyaan terbuka dan tertutup. Jenis pertanyaan berkaitan dengan pengalaman, pendapat, perasaan dan berkenaan dengan indra dan demografi. Keabsahan data berdasarkan obyektivitas berkenaan derajat kesepakatan antar banyak orang. Kuesioner dilakukan uji pada kelompok mahasiswa FKIP UPR diperoleh hasil 15 dari 18 pertanyaan dinyatakan valid berdasarkan uji signifikansi koefisien korelasi. Pertanyaan tidak valid tidak digunakan dalam penelitian, sehingga tersisa 15 butir pertanyaan. Nilai koefisien reliabilitas 0,74 sehingga dinyatakan reliabel.

Sampel penelitian adalah mahasiswa Fakultas Keguruan dan Ilmu Pendidikan (FKIP) Universitas Palangka Raya sebanyak 96 mahasiswa. Teknik pengambilan sampel secara simpel random sampling. Variabel yang akan diukur adalah perubahan pola belajar, perilaku sosial, perilaku kesehatan mahasiswa. Teknik pengambilan data menggunakan kuesioner online, yang berisi pertanyaan tertutup dan terbuka analisis dan model statistik yang digunakan. Kuesioner menggunakan google form. Analisis dilakukan secara kuantitatif, yaitu analisa univariat untuk mengetahui gambaran data yang telah dikumpulkan dengan distribusi frekuensi.

\section{Hasil}

Penelitian dilakukan pada mahasiswa Fakultas Keguruan dan Ilmu Pendidikan (FKIP) Universitas Palangka Raya diikuti oleh 96 mahasiswa, sebesar 2,6\% mahasiswa FKIP UPR. Partisipan merupakan mahasiswa dari berbagai program studi/jurusan di lingkungan FKIP. Mahasiswa yang mengikuti terdiri dari berbagai angkatan tahun masuk, yaitu tahun 2019, 2018, 2017 dan 2016. Mahasiswa sebagian besar berasal dari Kalimantan Tengah dan sebagian lain berasal dari provinsi lain di Kalimantan, serta dari daerah lain yaitu Sumatera dan Jawa. 
Mahasiswa sebagian besar tidak ada aktivitas lain, yaitu kuliah saja, sebesar $71.9 \%$ dan sebagian lain kuliah dan bekerja sebesar $28.1 \%$. Latar belakang mahasiswa tercantum pada gambar 1. Selama masa pandemi, perkuliahan dilakukan secara online, beberapa mahasiswa pulang kampung (mengikuti perkuliahan secara daring dari rumah di kampung) sebesar 48 orang, sebagian lagi tetap tinggal di kos/asrama di Palangka Raya 30 orang, sebagian lagi pulang pergi 6 orang dan sisanya memang bertempat tinggal di Palangka Raya 12 orang.

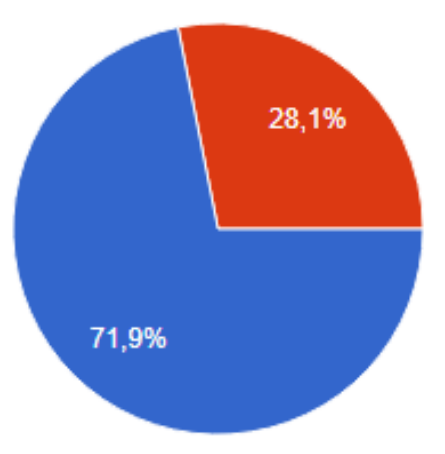

\section{Gambar 1. Latar Belakang Mahasiswa}

Pandemi berdampak pada banyak aspek dalam kehidupan sehari-hari. Beberapa orang di antaranya meski mengalami dampak namun mampu beradaptasi, namun beberapa lainnya merasakan dampak yang lebih berat. Partisipan sebanyak 59.4\% mengalami dampak langsung maupun tidak langsung, dan sebesar 40,6\% dapat memahami kondisi dan menyesuaikan.

\section{Dampak Pandemi Covid-19 terhadap Perilaku Belajar}

Perkuliahan dilakukan secara online sesuai Pedoman Umum Penyelenggaraan Pendidikan selama Masa Pandemi Covid-19. Panduan tersebut sesuai dengan Surat Edaran Menteri Pendidikan dan Kebudayaan serta mempertimbangkan edaran gubernur Kalimantan Tengah tentang Protokol Status Tanggap Darurat Bencana Pandemi Covid-19 di Lingkungan Pendidikan Provinsi Kalimantan Tengah. Perkuliahan full online merupakan hal yang baru sehingga beberapa mahasiswa mengalami kesulitan. Pemanfaatan teknologi itu sendiri pun merupakan hal yang baru sehingga membutuhkan adaptasi, sementara beberapa daerah mengalami kendala jaringan.

Strategi belajar online, memberikan kondisi yang berbeda, beberapa merasa kesulitan menangkap materi dan kesulitan belajar. Hasil penelitian menunjukkan bahwa sebanyak 78,1\% tidak mengalami kendala atau mengalami kendala tetapi sudah teratasi, sedangkan 21,9\% lainnya mengalami kendala untuk mengikuti perkuliahan online. Kondisi selama perkuliahan online dijelaskan dalam tabel 1.

Tabel 1. Kondisi selama Perkuliahan Online di masa Pandemi

\begin{tabular}{lcc}
\hline Kondisi selama Perkuliahan Online & $\begin{array}{c}\text { Jumlah } \\
\text { (f) }\end{array}$ & $\begin{array}{c}\text { Persentase } \\
\mathbf{( \% )}\end{array}$ \\
\hline $\begin{array}{l}\text { Tidak ada kendala atau } \\
\text { ada kendala tetapi sudah teratasi }\end{array}$ & 75 & $78.1 \%$ \\
Mengalami kendala & 21 & $21.9 \%$ \\
\hline
\end{tabular}

Beberapa mahasiswa mengatakan materi lebih sulit dipahami dan lebih nyaman tatap muka langsung. Semua mata kuliah diberikan secara daring, memungkinkan pembelajaran mandiri yang lebih banyak 
sehingga mahasiswa merasa lebih banyak tugas yang harus dikerjakan, lebih banyak di depan laptop atau HP sehingga mata lelah. Biaya paket internet yang diperlukan lebih banyak, baik untuk mengikuti kuliah maupun mengerjakan dan mengumpulkan tugas. Sementara mereka yang terdampak secara ekonomi, harus membantu orang tua bekerja sehingga waktu belajar lebih sedikit.

Perkuliahan dilakukan secara daring membuat jadwal perkuliahan lebih fleksibel, sehingga ada kalanya dilakukan di luar jadwal perkuliahan. Pembelajaran online memiliki keterbatasan pada pembelajaran praktikum, karena tidak bisa melakukan langsung di lapangan. Selain itu, mereka yang biasanya presentasi di depan kelas dan diskusi tanya jawab tidak bisa dilakukan lagi.

Mahasiswa yang merasa tidak ada kendala atau sudah bisa mengatasi kendala (78,1\%), sebanyak 8\% diantaranya bahkan merasakan menjadi belajar lebih giat. Perkuliahan online memungkinkan pertemuan tatap muka dengan dosen dan teman-teman juga memberikan rasa senang serta membantu memahami materi perkuliahan. Hal positif lain adalah lebih memanfaatkan teknologi, lebih banyak mengetahui aplikasi yang bisa membantu kuliah online.

Keterampilan baru yang diperoleh selama masa pandemi seperti yang digambarkan pada gambar 2, tidak hanya keterampilan terkait mata kuliah yang dipelajari, misalnya keterampilan bermain basket, penanganan cedera, dan lainnya tetapi juga menjadi lebih dekat dengan teknologi. Perkuliahan diberikan dengan metode beragam sesuai kontrak perkuliahan. Sebagian besar mahasiswa, sebanyak $52 \%$ mengatakan download dan menggunakan aplikasi baru dalam kegiatan perkuliahan dan kegiatan lain yang mendukung perkuliahan. Beberapa platform yang digunakan adalah google classroom, room, google meet, platform dari fakultas setempat, termasuk Whats App dan Telegram.

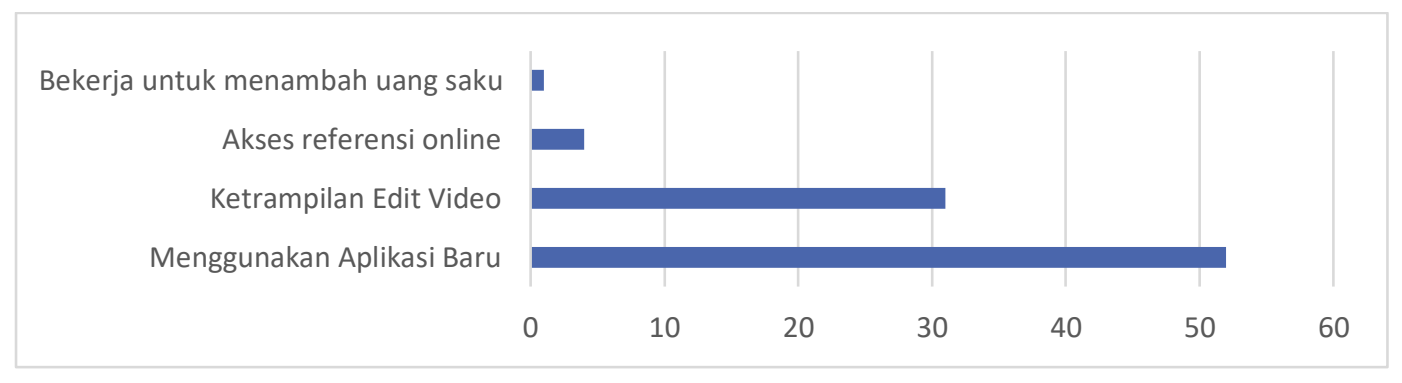

\section{Gambar 2. Keterampilan Baru selama Perkuliahan Online}

Materi praktik disampaikan dengan memberikan panduan kemudian mahasiswa mempraktikkan sehingga seringkali mahasiswa melaporkan kegiatan praktik melalui video. Sebanyak 32\% mahasiswa mengatakan mempelajari keterampilan baru terkait edit video dengan berbagai macam aplikasi. Mahasiswa menjadi lebih menguasai microsoft office (word, excel, power point) dan pdf serta canva dan blender.

Perilaku belajar lain adalah lebih sering membaca jurnal atau buku online, membaca dari situs wikipedia Indonesia, aplikasi membaca gratis seperti ipusnas, duolingo dan quora. Selain itu belajar dari video yang memuat informasi umum dan pengetahuan umum di youtube. Selain kegiatan belajar mahasiswa juga mendapat pengalaman baru yaitu bekerja untuk menambah uang saku.

Selama mengikuti perkuliahan daring, sebanyak 78,1\% mengalami kendala dan 21,9\% sisanya cukup adaptif, mampu menyesuaikan. Kendala yang dialami dijelaskan pada gambar 3 yaitu jaringan yang kurang memadai, kuota terbatas, materi lebih susah dipahami. Kuliah daring dalam bentuk interaksi langsung seperti room dan google meet, terkendala jaringan seringkali suara tidak jelas dan membutuhkan kuota lebih banyak. Metode interaksi tidak langsung memiliki keterbatasan dalam diskusi. 


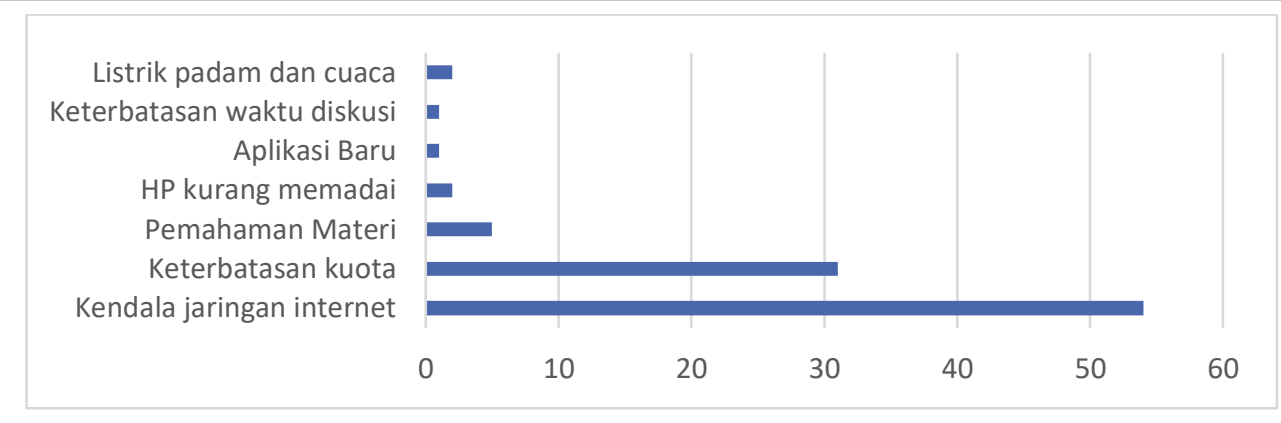

\section{Gambar 3. Kendala Perkuliahan Online}

Mahasiswa yang akan mengikuti ujian, harus memenuhi protokol kesehatan untuk proses pendaftaran dan ujian seminar, yang pada waktu itu terkendala secara teknis. Kendala juga dialami mahasiswa yang melakukan penelitian. Proposal yang telah disusun memerlukan interaksi langsung, atau pengambilan data di sekolah dan di tempat lain. Status tanggap bencana mengharuskan belajar dari rumah sehingga mahasiswa memiliki kendala dalam pengumpulan data.

\section{Dampak Pandemi Covid-19 terhadap Interaksi Sosial}

Pembatasan sosial memberikan peluang komunikasi dan relasi sosial melalui dunia maya. Hal itu pula yang dialami responden pada penelitian ini. Teknologi komunikasi memiliki peranan dalam menjaga interaksi sosial individu dengan individu maupun dengan kelompok. Komunikasi online meningkat dialami sebanyak 80,2\% responden, seperti yang tercantum pada gambar 4. Sebanyak 34,4\% mengatakan lebih dekat dengan keluarga melalui tatap muka tidak langsung, 39,6\% masih bertemu keluarga secara tatap muka langsung, 16,7\% tidak bertemu dengan keluarga, sisanya mengatakan jarang bertemu dan lainnya.

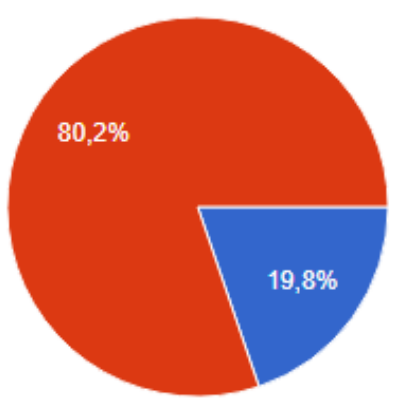

Tidak
Komunikasi online meningkat

\section{Gambar 4. Perubahan Relasi Sosial dalam Dunia Maya}

Interaksi sosial individu dengan individu maupun kelompok juga terjadi pada kegiatan ibadah. Kegiatan ibadah juga terdampak karena sebagian besar aktivitas di rumah saja, tempat ibadah ditutup. Sebanyak 48,9\% mengatakan lebih taat beribadah, lebih sering berdoa agar terhindar dari sakit, namun sebesar 36,5\% mengatakan perilaku ibadah tetap seperti sebelum pandemi dan sisanya tidak menjawab, lebih jarang mengikuti ibadah dan lainnya. Kegiatan ibadah dilakukan di rumah, bersama keluarga dan dilakukan secara online, beberapa daerah masih menyelenggarakan ibadah dengan menerapkan protokol kesehatan. Berikut pernyataan terkait perubahan perilaku ibadah.

“...biasa pengajian, sekarang pengajian onlen nggak bisa ikut dikarenakan sulitnya jaringan."

"... ibadah online menurut saya sangat kurang rasanya menyampaikan rasa ke Tuhan"

"... saat beribadah sungguh singkat, dan orang yang mengikuti ibadahnya juga sedikit." 


\section{Dampak Pandemi Covid-19 terhadap Perilaku Kesehatan}

Informasi terkait pandemi membuat sebagian besar merasa over protektif. Hasil penelitian pada tabel 3 menunjukkan bahwa 51\% lebih mudah menaruh curiga ketika ada yang sakit atau menunjukkan gejala sakit, dan 42,7\% lainnya segera mencari pengobatan sendiri jika merasakan badan tidak nyaman. Perilaku over protektif "lebih mudah menaruh curiga" terjadi ketika dalam kondisi ada orang lain yang bersin, batuk atau terlihat sakit, maka ada rasa was-was dan berpikir kalau orang tersebut mungkin menderita covid-19. Mahasiswa sebagian besar tergerak melakukan kegiatan sosial terkait pandemi, tetapi tidak melakukan secara langsung yaitu sebesar 77,1\%.

\section{Tabel 2. Perilaku Over Protektif pada Masa Pandemi}

\begin{tabular}{lcc}
\hline \multicolumn{1}{c}{ Perilaku $\boldsymbol{O}$ ver Protektif } & $\begin{array}{c}\text { Jumlah } \\
\text { (f) }\end{array}$ & $\begin{array}{c}\text { Persentase } \\
(\mathbf{0})\end{array}$ \\
\hline $\begin{array}{l}\text { Lebih mudah menaruh curiga ketika ada } \\
\text { yang mengalami tanda/gejala sakit }\end{array}$ & 49 & $51 \%$ \\
$\begin{array}{l}\text { Mencari pengobatan sendiri jika merasakan } \\
\text { tanda/gejala sakit }\end{array}$ & 31 & $32 \%$ \\
Segera ke dokter jika merasa kurang sehat & 16 & $17 \%$ \\
\hline
\end{tabular}

Selain kendala yang disampaikan terkait perkuliahan online, aktivitas olahraga, ternyata pandemi juga berdampak positif. Perubahan positif yang dirasakan adalah lebih dekat dengan keluarga, lebih sering menjalin komunikasi dengan saudara atau teman, lebih hemat biaya hidup, tambah ilmu teknologi, lebih banyak beribadah. Sebagian kecil tidak merasakan perubahan yaitu sebesar 3,1\%.

Masa pandemi memaksa untuk menerapkan pola hidup sehat. Berbagai pihak menyampaikan informasi terkait protokol kesehatan pencegahan penularan covid-19. Hasil penelitian menunjukkan perubahan pola hidup sehat yang dilakukan dalam kehidupan sehari-hari. Tindakan pola hidup sehat yang paling banyak diterapkan adalah kebiasaan mencuci tangan, selanjutnya penggunaan masker, olahraga, pola makan sehat.

Perubahan pola makan sebagian besar berkurang yaitu sebanyak 45.8\%. Mahasiswa menyampaikan uang saku berkurang, sebagian yang lain yang kuliah sambil bekerja mengatakan pendapatan berkurang, sehingga mereka harus menghemat pengeluaran untuk makan dan toko lebih banyak yang tutup sehingga pilihan untuk makan juga terbatas. Rincian tercantum pada tabel 2 sebagai berikut.

\section{Tabel 3. Perubahan Pola Makan Selama Masa Pandemi}

\begin{tabular}{lcc}
\hline \multicolumn{1}{c}{ Pola Makan } & $\begin{array}{c}\text { Jumlah } \\
(\mathbf{f})\end{array}$ & $\begin{array}{c}\text { Persentase } \\
\mathbf{( \% )}\end{array}$ \\
\hline Berkurang & 44 & $45.8 \%$ \\
Tetap & 42 & $35.4 \%$ \\
Lebih memperhatikan pola makan & 18 & $18.8 \%$ \\
\hline
\end{tabular}

Berbagai macam upaya dilakukan untuk meningkatkan daya tahan tubuh. Sebagian besar memilih berjemur 45,8\%, kemudian minum jamu, ramuan atau herbal lainnya sebesar 28\%. Metode lain yang dipilih adalah olahraga, konsumsi suplemen berupa vitamin dan mineral, menerapkan pola makan sehat, banyak minum air putih, meningkatkan konsumsi buah dan sayuran, dan lainnya.

Pola olahraga juga mengalami perubahan. Fase awal pandemi semua aktivitas dilakukan di rumah, tidak keluar jika tidak dirasa penting sekali, terlebih Kota Palangka Raya menerapkan Pembatasan 
Sosial Berskala Besar (PSBB) pada tanggal 11 - 24 Mei 2020. Hasil penelitian menunjukkan sebagian besar, yaitu 43,8\% aktivitas olahraga berkurang. Hasil penelitian terkait perubahan pola olahraga disajikan pada gambar 5.

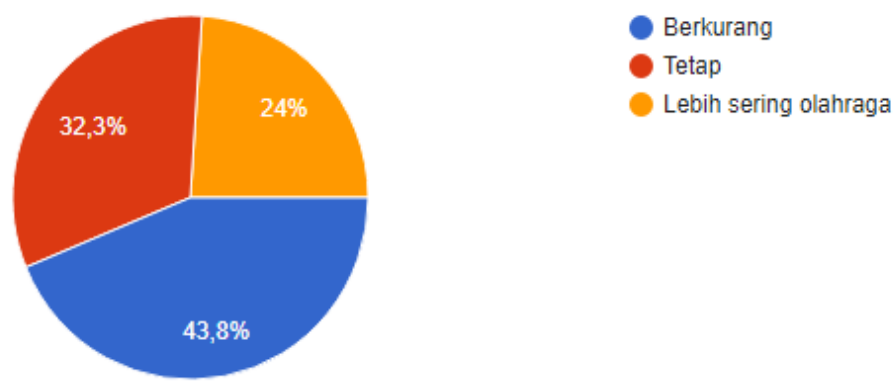

\section{Gambar 5. Perubahan Pola Olahraga}

Mereka yang berolahraga melakukan latihan atau olahraga di rumah, baik di dalam rumah maupun di halaman rumah, sebesar $64,6 \%$, sebesar $22,9 \%$ tidak ada program latihan dan sisanya melakukan olahraga tetapi tidak rutin. Jenis olahraga yang dilakukan adalah jogging, bola voli, basket. Latihan dilakukan secara mandiri, tidak beregu seperti dalam permainan. Mereka yang tidak olahraga melakukan aktivitas fisik berupa berjalan kaki atau berkebun.

Penelitian dilakukan pada masa pandemi untuk mengkaji perubahan belajar, interaksi sosial dan perilaku kesehatan yang dirasakan sejak awal masa pandemi sampai saat pengambilan data, serta sikap terhadap konsep new normal yang sudah mulai diwacanakan, sementara untuk Palangka Raya sendiri masih dalam pertimbangan apakah akan perpanjangan masa PSBB. Sikap menghadapi konsep new normal dijelaskan dalam gambar 7. Sikap hampir berimbang antara tidak siap adaptasi (32,3\%) dan siap adaptasi kebiasaan baru (30.25). Beberapa upaya dilakukan untuk mempersiapkan adaptasi kebiasaan baru, yaitu meningkatkan daya tahan tubuh (56,3\%), mempersiapkan starter kit $(54,2 \%)$, mencari informasi tentang adaptasi kebiasaan baru (38,5\%), lebih hati-hati (1\%) dan sisanya mengatakan tidak ada persiapan khusus. Angka 1 menunjukkan sikap tidak siap, takut, tidak bisa adaptasi dan nomor 5 menunjukkan siap adaptasi.

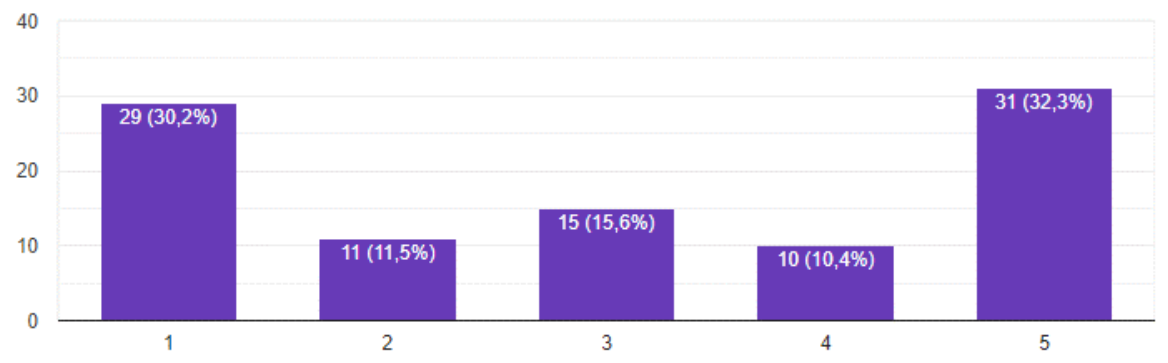

Gambar 7. Sikap dalam Menghadapi New Normal

\section{Pembahasan}

Penelitian yang dilakukan di India menunjukkan responden memiliki sikap sebagian besar baik yaitu mematuhi himbauan pemerintah terkait protokol kesehatan, namun lebih dari $80 \%$ orang disibukkan oleh pemikiran COVID-19 (Roy et al., 2020). Penelitian ini menunjukan beberapa hasil yang sama yaitu sikap yang cukup baik namun sebagian besar merasakan kecemasan, yang dalam penelitian ini terlihat dari perilaku over protektif akibat informasi yang diterima. Beberapa di antaranya 
mengatakan harus berada di kampung halaman karena orang tua mencemaskan kampus berada di kota Palangka Raya yang merupakan zona merah.

Hasil penelitian menunjukkan bahwa sebagian besar mahasiswa mengalami kendala perkuliahan, berupa jaringan internet, kuota internet untuk mengikuti aktivitas perkuliahan dan penugasan, pemahaman materi dan lainnya. Kondisi tersebut serupa dengan penelitian pada Program Studi Ilmu Keolahragaan Universitas Negeri Surabaya bahwa terdapat beberapa kendala perkuliahan daring. Kendala tersebut meliputi paket kuota data dan sinyal yang minim ditambah dengan teknis perkuliahan yang memberatkan mahasiswa dengan penugasan yang banyak dengan deadline pengerjaan yang pendek (Sulata \& Hakim, 2020).

Kondisi tersebut sejalan Nicola, Alsafi, Sohrabi, Kerwan, \& Al-jabir (2020) dimana terdapat kesenjangan pada suatu populasi yang memiliki pendapatan tinggi dapat memenuhi akses teknologi dan mengikuti pendidikan secara digital. Kendala lain yang juga ditemui pada penelitian ini adalah pembatasan kegiatan penelitian selain covid-19, sementara proposal yang telah dirancang mahasiswa pada periode sebelumnya bahkan mungkin membutuhkan kontak fisik dan perlu mengabaikan physical distancing sehingga perlu dipertimbangkan metode baru.

Penyebab utama tidak optimalnya penggunaan internet dalam pembelajaran menurut Pujilestari (2020) adalah kurangnya ketersediaan sumber daya manusia, transformasi teknologi, infrastruktur telekomunikasi dan perangkat hukumnya yang mengaturnya. Selain itu masih terdapat kekurangan pada infrastruktur teknologi telekomunikasi, multimedia dan informasi. Akses internet perlu diperluas. Mahasiswa yang tinggal di area kampus di kota Palangka Raya pada umumnya tidak ada kendala namun mahasiswa yang tinggal di daerah pada umumnya mengalami kendala sehingga beberapa dari mereka harus mencari titik-titik yang mendapat sinyal bagus.

Berbeda dengan penelitian di Jurusan Pendidikan Olahraga dan Kepelatihan FKIP Universitas Jambi oleh Indrayana et al. (2020) bahwa mahasiswa merasakan kemudahan dalam perkuliahan karena dapat diakses dimana saja dan kapan saja, rupanya hal tersebut tidak seperti yang dialami mahasiswa di Universitas Palangka Raya. Sebagian besar mahasiswa di kampung sehingga banyak yang mengalami kendala jaringan internet. Mahasiswa yang berasal dari jurusan Pendidikan Jasmani, Kesehatan dan Rekreasi (PJKR) mengatakan pembelajaran tatap muka, praktik langsung di lapangan lebih menyenangkan daripada pembelajaran daring.

Selaras dengan Firman \& Rahayu (2020) bahwa pembelajaran online memberikan fleksibilitas serta mampu mendorong munculnya kemandirian belajar dan motivasi untuk lebih aktif dalam belajar. Kondisi tersebut juga dialami mahasiswa UPR dalam penelitian ini, mereka harus belajar mandiri untuk memahami materi dan memenuhi tugas serta lebih banyak mencari referensi dari jurnal atau buku online, situs online dan aplikasi.

Penelitian Herliandry \& Suban (2020) menuliskan pembelajaran online menjadi solusi efektif untuk mengaktifkan kelas. Universitas Palangka Raya berlokasi di zona merah, metode kuliah online diharapkan efektif untuk mengurangi resiko penyebaran penularan. Namun evaluasi kegiatan perkuliahan beberapa kondisi belum bisa terlaksana secara sempurna mengingat beberapa lokasi terkendala jaringan. Beberapa solusi dilakukan misalnya dengan memperpanjang rentang waktu pengumpulan tugas, memilih dan menyepakati metode yang lebih luas menjangkau peserta didik.

Kendala dalam penerapan pembelajaran online yang dijelaskan (Abidin, Rumansyah, \& Arizona, 2020) di antaranya kuota internet yang terbatas dan masih belum familiarnya tenaga pendidik beserta peserta didik dalam mengaplikasikannya. Kondisi tersebut memerlukan strategi khusus lebih masif. Salah satu pendekatan pembelajaran adalah pembelajaran berbasis proyek, yang peluang kepada 
peserta didik untuk mempelajari konsep secara mendalam sekaligus meningkatkan hasil belajarnya. Interaksi dalam pendekatan belajar ini dapat terjadi secara efektif dengan memanfaatkan proses penyelidikan yaitu dengan mengarahkan peserta didik untuk membuat atau mengembangkan produk yang aplikatif dan berkaitan dengan kehidupan sehari-hari.

Konsep adaptasi kebiasaan baru memungkinkan pertemuan tatap muka di kelas dengan memperhatikan protokol kesehatan. Ruang belajar dilengkapi dengan fasilitas mencuci tangan, menjaga jarak antar mahasiswa, pemakaian masker dan lainnya. Metode tatap muka diperlukan pada capaian pembelajaran tertentu yang lebih efektif jika dilakukan secara tatap muka sedangkan capaian pembelajaran lain tetap dilakukan secara online. Model pembelajaran tersebut adalah pembelajaran berbasis blended learning (PBBL). PBBL merupakan pembelajaran yang mengombinasikan keunggulan belajar melalui tiga sumber belajar utama, yaitu tatap muka, offline, dan online (Dwiyogo, 2018).

Metode blended learning seperti yang dilakukan pada Jurusan Pendidikan Jasmani, Kesehatan, Dan Rekreasi Fakultas Keguruan dan Ilmu Pendidikan Universitas Nusantara PGRI Kediri memiliki efektivitas yang baik. Pengembangan pembelajaran berbasis blended learning membantu mahasiswa lebih maksimal dalam proses pembelajaran dan membantu memudahkan tugas pendidik (Kristiono, Dwiyogo, \& Hariadi, 2019). Metode tersebut dapat dikembangkan sebagai metode yang efektif pada masa adaptasi kebiasaan baru ini. Beberapa mata kuliah terutama dengan materi praktik dan konsep dasar membutuhkan pertemuan tatap muka, lainnya dapat dilakukan secara online dan offline.

Alternatif metode pembelajaran serupa dengan model pembelajaran yang diungkapkan oleh Jayul \& Irwanto (2020) dimana metode daring sebagai alternatif, namun untuk memfasilitasi metode pembelajaran praktik menggunakan metode dengan aplikasi video. Prinsip pembelajaran berdasarkan tiga aspek penilaian dalam pendidikan yaitu kognitif, afektif, dan psikomotor. Mahasiswa diminta melakukan praktik secara mandiri di rumah masing-masing kemudian hasil belajar disampaikan kepada dosen dalam bentuk video, baik secara offline maupun live.

Penelitian dilakukan pada masa pembatasan sosial berskala besar. Selain aktivitas kampus, aktivitas sosial dan perekonomian juga terdapat pembatasan. Perkuliahan praktik, basket misalnya yang diungkapkan responden, pembelajaran dilakukan secara mandiri di rumah, kemudian hasil kegiatan dilaporkan kepada dosen. Kegiatan yang harus dilakukan secara beregu, dilakukan bersama dengan anggota keluarga atau orang lain yang satu rumah/lingkungan. Tipe pembelajaran tersebut serupa dengan rancangan pembelajaran model distance learning sebagai potensi pembelajaran Pendidikan Jasmani Olahraga dan Kesehatan (PJOK) pada anak sekolah dan collaborative approach dengan orang tua siswa melalui lembar pengamatan aktivitas belajar (Herlina \& Suherman, 2020).

Komunikasi sosial dalam dunia maya meningkat selama masa pandemi. Mereka mendapat informasi terkait status perkembangan covid-19, upaya pencegahan serta kegiatan sosial terkait covid-19. Hal ini sesuai (Sampurno, Kusumandyoko, \& Islam, 2020) bahwa media dan sumber pengetahuan selalu berkembang. Media sosial memiliki peran dalam edukasi kesehatan masyarakat untuk mempercepat penyebaran informasi terkait covid-19. Pengembangan sumber media statis berupa buku diaplikasikan dalam bentuk yang dinamis dan virtual, yang dalam penelitian ini beberapa mahasiswa memanfaatkan referensi belajar secara virtual.

Informasi melalui media sosial dan media online lain perlu dilakukan batasan dan penyaringan. Hasil penelitian di China diketahui bahwa orang-orang yang lebih muda berada pada risiko tinggi menampilkan masalah psikologis. Masalah yang dilaporkan yaitu gangguan kecemasan, gejala depresi, dan kurang tidur. Orang yang lebih muda melaporkan prevalensi gangguan kecemasan dan gejala depresi yang lebih tinggi daripada orang tua (Huang \& Zhao, 2020). Hal tersebut perlu menjadi perhatian karena mahasiswa sebagai anggota masyarakat sebagai kelompok orang lebih muda 
sedangkan sebagian kecil mahasiswa mengatakan stress karena banyak tugas dan kurang memahami materi yang diberikan.

Kesulitan memahami materi perkuliahan serupa dengan penelitian pada Stikes Rajekwesi Bojonegoro, dimana $54.5 \%$ sulit memahami materi perkuliahan, kreativitas mahasiswa 50\%, pelaksanaan tugas oleh mahasiswa $56.5 \%$ sulit dan lambat, dan $41 \%$ mahasiswa kurang aktif selama perkuliahan (Rahmawati \& Putri, 2020). Sulit pemahaman dialami mahasiswa UPR, mereka lebih nyaman tatap muka langsung, bisa bertanya langsung kepada dosen. Kreativitas ditemukan dari keterampilan diluar kompetensi kuliah berupa mengenal aplikasi baru, editing video, dan lainnya. Pelaksanaan tugas sulit dan lambat serta kurang aktif karena terkendala jaringan dan banyaknya tugas.

Serupa dengan studi di China dimana kesehatan mental mahasiswa harus dipantau selama pandemi. Penelitian tersebut menunjukkan bahwa efek ekonomi dan efek pada kehidupan sehari-hari, serta keterlambatan dalam kegiatan akademik secara positif terkait dengan gejala kecemasan $(\mathrm{P}<0,001)$ namun dukungan sosial berkorelasi negatif dengan tingkat kecemasan $(\mathrm{P}<0,001)$ (Cao et al., 2020). Hal yang sama dialami oleh mahasiswa pada penelitian ini. Mahasiswa yang tinggal bersama orang tua, harus membantu lebih banyak kegiatan orang tua, beberapa lagi harus bekerja sehingga merasakan kecemasan ketika tidak dapat mengikuti perkuliahan online secara optimal.

Pandemi covid-19 banyak memberikan dampak terhadap perilaku kesehatan, baik melalui himbauan pemerintah, informasi pada media sosial termasuk gerakan atau protokol yang diterapkan di pintu masuk desa, fasilitas umum dan perkantoran. Hasil penelitian menunjukkan perilaku yang paling banyak diterapkan adalah mencuci tangan. Perubahan periaku dalam hal ini yang perlu dikaji adalah apakah perubahan perilaku tersebut karena terpaksa (compliance), meniru (identification), menghayati (internalization). Jika perilaku mencuci tangan adalah keterpaksaan karena semata-mata dilakukan karena diminta oleh petugas, maka perubahan perilaku tersebut cenderung tidak efektif, namun bila mencuci tangan dilakukan karena kesadaran untuk mencegah penularan covid-19, ia merasa pantas dan harus ada pada dirinya, sehingga perilaku tersebut lebih efektif (Agustini, 2019).

Pelaksanaan pembatasan sosial lebih terkendali karena perkuliahan dilakukan secara online, sehingga mencegah keramaian atau perkumpulan mahasiswa. Hal tersebut juga disebutkan oleh Firman \& Rahayu (2020) pada studi yang dilakukan pada mahasiswa Pendidikan Biologi Universitas Sulawesi Barat. Selain pembatasan sosial atau physical-social distancing, perilaku kesehatan yang diterapkan dalam penelitian ini adalah pemakaian masker, kebiasaan cuci tangan.

Perilaku kesehatan terkait physical distancing yang baik juga dilaksanakan oleh 55,9\% mahasiswa UIN Syarif Hidayatullah Jakarta. Determinan physical distancing adalah jenis kelamin perempuan, pengetahuan yang baik terkait physical distancing dan dukungan keluarga. Perilaku physical distancing pada mahasiswa perempuan lebih baik (Syadidurrahmah, Muntahaya, Islamiyah, \& Fitriani, 2020). Namun pada penelitian ini tidak melakukan analisis berdasarkan faktor determinan tersebut.

Sementara upaya menghambat penularan virus membutuhkan perubahan perilaku yang signifikan, tidak sekedar mematuhi himbauan pemerintah tetapi dari kesadaran. Berbagai aspek konteks sosial dan budaya mempengaruhi tingkat dan kecepatan perubahan perilaku. Aspek konteks sosial dapat membantu pembuat keputusan mengidentifikasi faktor risiko dan secara efektif melakukan intervensi. Keterlibatan tokoh agama, tokoh masyarakat dinilai efektif dalam menyebarluaskan pesan kesehatan. Pembatasan sosial atau jaga jarak fisik juga memberikan kontribusi dalam pencegahan penularan covid-19 (Bavel et al., 2020). 
Covid-19 merupakan penyakit infeksi, dimana penyakit infeksi memiliki hubungan timbal balik dengan status gizi seseorang. Tubuh membutuhkan zat gizi yang lebih banyak untuk memenuhi peningkatan metabolisme pada orang yang menderita infeksi. Demikian pula sebaliknya, seseorang yang gizinya kurang, mempunyai risiko terkena penyakit infeksi karena pada keadaan kurang gizi daya tahan menurun sehingga kuman penyakit lebih mudah masuk dan berkembang (Kementerian Kesehatan RI, 2014). Jadi seyogyanya kebutuhan gizi harus tetap diperhatikan untuk menjaga daya tahan tubuh. Gizi seimbang sebetulnya tidak harus mahal, namun kondisi mahasiswa tidak terbiasa mempersiapkan dan masak sendiri menjadi kendala.

Hasil penelitian menunjukkan perubahan pola makan pada mahasiswa yang pada umumnya berkurang. Hal tersebut bertolak belakang dengan (Ammar et al., 2020) dimana jumlah makanan utama secara signifikan lebih tinggi selama isolasi di rumah $(t=5,83, p<0,001, d=0,22)$. Selain perbedaan terdapat pula kesamaan, yaitu pola konsumsi makanan yang tidak sehat dilihat dari jenis makanan. Mahasiswa memiliki keterbatasan keuangan dan beberapa toko/penjual makanan tutup sehingga mereka makan seadanya tanpa mempertimbangkan konsep gizi seimbang.

Kondisi yang berbeda ditemukan pada penelitian Saragih \& Mulawarman (2020) bahwa responden mengalami peningkatan frekuensi makan sebanyak 54,5\%, peningkatan keragaman konsumsi pangan sebanyak $59 \%$, dan jumlah konsumsi makan yang meningkat sebanyak $51 \%$. Mahasiswa secara umum frekuensi, keragaman dan jumlah berkurang. Hal tersebut dimungkinkan karena kekhawatiran kekurangan makanan, pada penelitian Saragih \& Mulawarman (2020) jumlah responden yang tidak khawatir kekurangan makanan lebih tinggi yaitu sebesar $54.5 \%$.

Mahasiswa yang sebelumnya memiliki program latihan, sebagian tetap melakukan latihan di rumah. Sebagian mahasiswa yang merupakan atlet merasa kurang bersemangat karena tidak bisa mengikuti pertandingan. Hal tersebut sesuai dengan Susanto (2020) bahwa beberapa event olahraga menjadi tertunda. Olahraga atau program latihan tetap dapat dilakukan agar tubuh bugar. Pelaksanaan olahraga perlu dilakukan secara aman, karena sejatinya olahraga dilakukan untuk meningkatkan imunitas atau daya tahan tubuh.

Upaya meningkatkan imun paling banyak dilakukan dengan cara berjemur, selanjutnya adalah minum ramuan tradisional atau herbal. Hal tersebut sejalan dengan Saragih \& Mulawarman (2020) dimana sebanyak $76 \%$ responden cenderung membuat empon-empon (rempah) sebagai minuman pada masa pandemi covid-19. Ramuan tradisional mudah dijangkau mahasiswa karena sebagian mahasiswa pulang ke kampung dan tinggal bersama orang tua atau keluarga.

Olahraga juga menjadi pilihan untuk meningkatkan daya tahan tubuh. Olahraga atau aktivitas fisik bermanfaat meningkatkan daya tahan tubuh, meningkatkan kebugaran, mengurangi stress, meningkatkan rasa percaya diri (Welis \& Rifki, 2013). Olahraga yang dapat meningkatkan imunitas adalah olahraga dengan intensitas ringan dan sedang. Aktivitas fisik yang dilakukan misalnya dengan berjalan cepat, naik turun tangga atau melakukan aktivitas rumah.

Mereka pun menuliskan harapan yang ingin dilakukan jika masa pandemi berakhir. Mereka ingin beraktivitas normal, melakukan hal-hal yang biasa dilakukan sebelum pandemi menyerang. Mereka menginginkan bertemu dengan keluarga, teman dan saudara serta kuliah tatap muka seperti sebelumnya bahkan bisa bertanding. Mereka merasa bersyukur lebih memahami dan menerapkan pola hidup sehat, lebih memperhatikan kesehatan dan lebih dekat dengan Tuhan. Lebih dari itu ketika pandemi berakhir, ingin segera mudik \& bertemu keluarga serta menikmati liburan. 


\section{Simpulan dan Rekomendasi}

Pandemi memberikan dampak bagi mahasiswa Universitas Palangka Raya, baik dalam perilaku sosial maupun kesehatan. Dampak perilaku belajar adalah penyesuaian menggunakan teknologi karena kuliah dilakukan dengan metode online, namun secara teknis terdapat kendala sinyal dan belum optimal untuk pembelajaran praktik. Dampak perilaku sosial berupa perilaku over protektif, lebih mudah menaruh curiga ketika ada orang lain yang tidak dalam kondisi sehat. Perubahan perilaku kesehatan berupa menurunnya pola makan, kebiasaan olahraga tetapi juga diimbangi upaya untuk meningkatkan imunitas atau daya tahan tubuh dengan berjemur, minum jamu, herbal atau ramuan tradisional dan olahraga.

Rekomendasi terkait kegiatan perkuliahan untuk dipertimbangkan metode yang dapat dijangkau secara luas. Strategi perkuliahan perlu dipertimbangkan pada metode yang fokus pada pencapaian hasil belajar. Metode blended learning dipertimbangkan, mengingat metode ceramah meski bukan metode terbaik tetapi tetap diperlukan dan dirindukan selama masa perkuliahan online.

\section{Ucapan Terima Kasih}

Ucapan terima kasih ditujukan kepada Rektor Universitas Palangka Raya dan Dekan Fakultas Keguruan dan Ilmu Keguruan (FKIP) Universitas Palangka Raya yang telah memberikan izin penelitian di lingkungan FKIP Universitas Palangka Raya.

\section{Daftar Pustaka:}

Abidin, Z., Rumansyah, \& Arizona, K. (2020). Pembelajaran Online Berbasis Proyek Salah Satu Solusi Kegiatan Belajar Mengajar Di Tengah Pandemi Covid-19. Jurnal Ilmiah Profesi Pendidikan, 5(1), 64-70. https://doi.org/10.29303/JIPP.V5I1.111

Agustini, A. (2019). Promosi Kesehatan. Yogyakarta: Deepublish Publisher.

Ammar, A., Brach, M., Trabelsi, K., Chtourou, H., Boukhris, O., Masmoudi, L., \& Bouaziz, B. (2020). Effects of COVID-19 Home Confinement on Eating Behaviour and Physical Activity : Results of the ECLB-COVID19 International Online Survey. Nutrients, 12, 1-13. Retrieved from www.mdpi.com/journal/nutrients

Bavel, J. J. Van, Baicker, K., Boggio, P. S., Capraro, V., Cichocka, A., Cikara, M., ... Weeden, K. A. (2020). Using Social and Behavioural Science to Support COVID-19 Pandemic Response. Nature Human Behaviour, 4(May), 460-471. https://doi.org/10.1038/s41562-020-0884-z

Cao, W., Fang, Z., Hou, G., Han, M., Xu, X., \& Dong, J. (2020). The Psychological Impact of the COVID-19 Epidemic on College Students in China. Psychiatry Research, 287(March), 112934. https://doi.org/10.1016/j.psychres.2020.112934

Dwiyogo, W. D. (2018). Pembelajaran Berbasis Blended Learning. Depok: PT. Raja Grafindo Persada.

Firman, F., \& Rahayu, S. (2020). Pembelajaran Online di Tengah Pandemi Covid-19. Indonesian Journal of Educational Science (IJES), 2(2), 81-89. https://doi.org/10.31605/ijes.v2i2.659

Gugus Tugas Covid-19 Kalimantan Tengah. (2020). Media Center Gugus Tugas Covid-19 Kalimantan Tengah. Palangka Raya. Retrieved from corona.kalteng.go.id

Herliandry, L. D., \& Suban, M. E. (2020). Jurnal Teknologi Pendidikan Pembelajaran Pada Masa 
Pandemi Covid-19, 22(1), 65-70.

Herlina, \& Suherman, M. (2020). Potensi Pembelajaran Pendidikan Jasmani Olahraga dan Kesehatan (PJOK) di Tengah Pandemi Corona Virus Disease (Covid)-19 di Sekolah Dasar. Tadulako Journal Sport Sciences and Physical Education, 0383.

Huang, Y., \& Zhao, N. (2020). Chinese Mental Health Burden during the COVID-19Ppandemic. Asian Journal of Psychiatry, 51(March), 102052. https://doi.org/10.1016/j.ajp.2020.102052

Indrayana, B., \& Sadikin, A. (2020). Penerapan E-Learning Di Era Revolusi Industri 4 . 0 Untuk Menekan Penyebaran Covid-19. Indonesion Journal of Sport Science and Coaching, 02(01), 46-55. Retrieved from http://online-journal.unja.ac.id/IJSSC/index

Jayul, A., \& Irwanto, E. (2020). Model Pembelajaran Daring Sebagai Alternatif Proses Kegiatan Belajar Pendidikan Jasmani di Tengah Pandemi Covid-19. Jurnal Pendidikan Kesehatan Rekreasi, 6(2), 190-199. https://doi.org/6, No. 2, Hal. 190 - 199, Juni 2020 DOI: $10.5281 /$ zenodo.3892262

Kementerian Kesehatan RI. (2014). Pedoman Giæi Seimbang. Jakarta: Kementerian Kesehatan Republik Indonesia.

Kristiono, I. D., Dwiyogo, W. D., \& Hariadi, I. (2019). Pembelajaran Ilmu Gizi Olahraga Berbasis Blended Learning pada Mahasiswa Pendidikan Jasmani, Kesehatan, dan Rekreasi. Jurnal Pendidikan: Teori, Penelitian, Dan Pengembangan, 4(2), 235-241.

Nicola, M., Alsafi, Z., Sohrabi, C., Kerwan, A., \& Al-jabir, A. (2020). Since January 2020 Elsevier has created a COVID-19 resource centre with free information in English and Mandarin on the novel coronavirus COVID-19. The COVID-19 resource centre is hosted on Elsevier Connect , the company's public news and information, (January).

Pujilestari, Y. (2020). Dampak Positif Pembelajaran Online Dalam Sistem Pendidikan Indonesia Pasca Pandemi Covid-19. Adalah, 4(1), 49-56. Retrieved from http://journal.uinjkt.ac.id/index.php/adalah/article/view/15394/7199

Rahmawati, \& Putri, E. M. (2020). Learning From Home dalam Perspektif Persepsi Mahasiswa Era Pandemi Covid-19. Prosiding Seminar Nasional Hardiknas, 17-24, 17-24. Retrieved from http://proceedings.ideaspublishing.co.id/index.php/hardiknas/article/view/3/3

Roy, D., Tripathy, S., Kar, S. K., Sharma, N., Verma, S. K., \& Kaushal, V. (2020). Study of knowledge, attitude, anxiety \& perceived mental healthcare need in Indian population during COVID-19 pandemic. Asian Journal of Psychiatry, 51(April), 102083. https://doi.org/10.1016/j.ajp.2020.102083

Sampurno, M. B. T., Kusumandyoko, T. C., \& Islam, M. A. (2020). Budaya Media Sosial, Edukasi Masyarakat, dan Pandemi COVID-19. SALAM: Jurnal Sosial Dan Budaya Syar-I, 7(5). https://doi.org/10.15408/sjsbs.v7i5.15210

Saragih, B., \& Mulawarman, U. (2020). Gambaran Kebiasaan Makan Masyarakat pada Masa Pandemi Covid-19. Jurnal Teknologi Industri Boga Dan Busana, 19(April). Retrieved from https://www.researchgate.net/publication/340830940

Sulata, M. A., \& Hakim, A. A. (2020). Gambaran Perkuliahan Daring Mahasiswa Ilmu Keolahragaan Unesa di Masa Pandemi Covid-19. Jurnal Kesehatan Olahraga, 08(03), 147-156. 
Susanto, N. (2020). Pengaruh Virus Covid-19 terhadap Bidang Olahraga Indonesia. Jurnal Stamina, 3(3), 145-153.

Syadidurrahmah, F., Muntahaya, F., Islamiyah, S. Z., \& Fitriani, T. A. (2020). Perilaku Physical Distancing Mahasiswa UIN Syarif Hidayatullah Jakarta pada Masa Pandemi COVID-19 Physical Distancing Behavior of Students of UIN Syarif Hidayatullah Jakarta dur- ing COVID19 Pandemic, 2(1), 29-37.

Welis, W., \& Rifki, M. S. (2013). Gizi untuk. Aktivitas Fisik dan Kebugaran. Sukabina Press. 